\title{
The effects of a biodegradable Mg-based alloy on the function of VSMCs via immunoregulation of macrophages through Mg- induced responses
}

\author{
Jing Wu ${ }^{1,2,3 \#}$, Liang Jin ${ }^{1,3,4,5 \#}$, Jin-Yun Tan ${ }^{6}$, Xia-Fang Chen ${ }^{1,7}$, Qing-Quan Wang ${ }^{8}$, Guang-Yin Yuan ${ }^{5,9}$, \\ Tong-Xin Chen ${ }^{1,2,3}$
}

${ }^{1}$ Division of Immunology, Institute of Pediatric Translational Medicine, Shanghai Children's Medical Center, School of Medicine, Shanghai Jiao Tong University, Shanghai, China; ${ }^{2}$ Allergy/Immunology Innovation Team, Shanghai Children's Medical Center, School of Medicine, Shanghai Jiao Tong University, Shanghai, China; ${ }^{3}$ Department of Rheumatology/Immunology, Shanghai Children's Medical Center, School of Medicine, Shanghai Jiao Tong University, Shanghai, China; ${ }^{4}$ College of Life Sciences, Zhejiang Chinese Medical University, Hangzhou, China; ${ }^{5}$ School of Biomedical Engineering, Med-X Research Institute, Shanghai Jiao Tong University, Shanghai, China; ${ }^{6}$ Department of Vascular Surgery, Huashan Hospital of Fudan University, Shanghai, China; ${ }^{7}$ Department of Neonatology, Shanghai Children's Medical Center, School of Medicine, Shanghai Jiao Tong University, Shanghai, China; ${ }^{8}$ The Fifth People's Hospital of Wuhu, Anhui, China; ${ }^{9}$ National Engineering Research Center of Light Alloys Net Forming and State Key Laboratory of Metal Matrix Composite, Shanghai Jiao Tong University, Shanghai, China

Contributions: (I) Conception and design: TX Chen, GY Yuan; (II) Administrative support: None; (III) Provision of study materials or patients: GY Yuan, L Jin; (IV) Collection and assembly of data: J Wu, L Jin, JY Tan, XF Chen, QQ Wang; (V) Data analysis and interpretation: J Wu, L Jin; (VI) Manuscript writing: All authors; (VII) Final approval of manuscript: All authors.

\#These authors contributed equally to this work as co-first authors.

Correspondence to: Tong-Xin Chen, MD, PhD. 1678 Dongfang Road, Pudong District, Shanghai 200127, China. Email: tongxinc@yahoo.com; Guang-Yin Yuan, PhD. 800 Dongchuan Road, Minhang District, Shanghai 200240, China. Email: gyyuan@sjtu.edu.cn.

Background: Restenosis is one of the worst side effects of percutaneous coronary intervention (PCI) due to neointima formation resulting from the excessive proliferation and migration of vascular smooth muscle cells (VSMCs) and continuous inflammation. Biodegradable Mg-based alloy is a promising candidate material because of its good mechanical properties and biocompatibility, and biodegradation of cardiovascular stents. Although studies have shown reduced neointima formation after $\mathrm{Mg}$-based CVS implantation in vivo, these findings were inconsistent with in vitro studies, demonstrating magnesium-mediated promotion of the proliferation and migration of VSMCs. Given the vital role of activated macrophage-driven inflammation in neointima formation, along with the well-demonstrated crosstalk between macrophages and VSMCs, we investigated the interactions of a biodegradable $\mathrm{Mg}-\mathrm{Nd}-\mathrm{Zn}-\mathrm{Zr}$ alloy (denoted JDBM), which is especially important for cardiovascular stents, with VSMCs via macrophages.

Methods: JDBM extracts and $\mathrm{MgCl}_{2}$ solutions were prepared to study their effect on macrophages. To study the effects of the JDBM extracts and $\mathrm{MgCl}_{2}$ solutions on the function of VSMCs via immunoregulation of macrophages, conditioned media (CM) obtained from macrophages was used to establish a VSMCmacrophage indirect coculture system.

Results: Our results showed that both JDBM extracts and $\mathrm{MgCl}_{2}$ solutions significantly attenuated the inflammatory response stimulated by lipopolysaccharide (LPS)-activated macrophages and converted macrophages into M2-type cells. In addition, JDBM extracts and $\mathrm{MgCl}_{2}$ solutions significantly decreased the expression of genes related to VSMC phenotypic switching, migration, and proliferation in macrophages. Furthermore, the proliferation, migration, and proinflammatory phenotypic switching of VSMCs were significantly inhibited when the cells were incubated with CMs from macrophages treated with LPS + extracts or LPS $+\mathrm{MgCl}_{2}$ solutions.

Conclusions: Taken together, our results suggested that the magnesium in the JDBM extract could affect the functions of VSMCs through macrophage-mediated immunoregulation, inhibiting smooth muscle hyperproliferation to suppress restenosis after implantation of a biodegradable $\mathrm{Mg}$-based stent. 
Keywords: Biodegradable Mg-based alloy; JDBM magnesium alloy; vascular smooth muscle cells (VSMCs); immunoregulation; macrophage

Submitted Mar 22, 2021. Accepted for publication Jun 24, 2021.

doi: $10.21037 / \mathrm{atm}-21-1375$

View this article at: https://dx.doi.org/10.21037/atm-21-1375

\section{Introduction}

Atherosclerosis is one of the leading causes of morbidity and mortality in developed countries (1). In recent decades, the incidence of atherosclerosis has been increasing rapidly in developing countries due to the increasing popularity of western lifestyles, resulting in this disease becoming a global health concern $(2,3)$. Percutaneous coronary intervention (PCI), which involves implanting a stent into a diseased artery, is regarded as an effective and widely acceptable atherosclerosis treatment (4). However, restenosis is still one of the major challenges associated with PCI in the clinic. Neointima formation is reported to be the main cause of restenosis, primarily due to excessive proliferation and migration of vascular smooth muscle cells (VSMCs) $(5,6)$.

VSMCs, which are major cellular components of the vasculature, are involved in various physiological and pathological changes in the vascular wall $(7,8)$. Because these cells are not terminally differentiated, VSMCs exhibit phenotypic and functional plasticity and play an important role in responding to vascular injury (8). Under physiological conditions, VSMCs exhibit a quiescentcontractile phenotype and regulate blood pressure and the redistribution of blood flow $(8,9)$. The quiescentcontractile phenotype of VSMCs is characteristic of the stable expression of specific proteins, such as $\alpha$-smooth muscle actin ( $\alpha$-SMA), SM22 $\alpha$, SM myosin heavy chain (MHC), myocardin (MyoC), and H1-calponin $(9,10)$. Once the vessel is injured or stimulated by external signals, VSMCs can switch from the contractile phenotype to the pro-inflammatory phenotype. The latter phenotype exhibits decreased expression of the proteins mentioned above and increased proliferation and motility, thereby promoting vascular wall repair (7). However, excessive VSMC phenotypic transformation is a critical pathomechanism of some vascular diseases, such as atherosclerosis, cerebral microangiopathy, and hypertension (10-12).

In recent years, biodegradable metallic stents, such as magnesium $(\mathrm{Mg})$-based stents, have been regarded as promising biomedical implants due to their good mechanical properties, biocompatibility, and biodegradability, which help to avoid sequelae such as late in-stent restenosis and neoatherosclerosis after implantation (6,12-14). Moreover, the rapid degradation of Mg-based stents, whose main degradation product is $\mathrm{Mg}$ ions, alters the vascular microenvironment, further affecting the immune response and revascularization in the vessel wall $(15,16)$. In fact, although previous data have demonstrated provascularization and proangiogenic effects of $\mathrm{Mg}$-based alloys in vitro and in vivo (15-17), only a few reports have studied the effects of alloys on VSMCs. Waksman et al. examined the biocompatibility of bioabsorbable $\mathrm{Mg}$ alloys in porcine coronary arteries, and the results showed that there was significantly less neointima formation in segments with $\mathrm{Mg}$ alloy stents than in those with stainless steel stents (18). Notably, this in vivo finding seems to be inconsistent with previous in vitro reports, showing that the $\mathrm{Mg}$-based alloy extract promoted the proliferation and migration of VSMCs (19). To date, the underlying mechanism of these seemingly contradictory effects of $\mathrm{Mg}$-based alloys in vivo and in vitro has remained unclear and needs to be elucidated.

In addition to the contribution of excessive VSMC proliferation and migration, neointima formation is also driven by local inflammation after PCI by means of early neutrophil recruitment followed by prolonged macrophage accumulation in stented arteries $(20,21)$. Restenosis resulting from intimal hyperplasia and the failure of reendothelization was reportedly correlated with an excessive inflammatory response (20). Macrophages play an essential role in the inflammatory response after PCI in terms of their polarization into M1-type (proinflammatory) and M2-type (anti-inflammatory) cells (22-26). M2 macrophages play a vital role in resolving inflammation by switching gene expression toward anti-inflammatory molecules (27). In particular, the complicated interaction between macrophages and VSMCs during vascular injury, which further leads to intimal hyperplasia, has been well demonstrated (28). Herein, we hypothesized that $\mathrm{Mg}$ based alloys might affect the migration and proliferation 
of VSMCs via immunoregulation by macrophages. The present study aimed to explore the potential mechanisms by which $\mathrm{Mg}$ in $\mathrm{Mg}$-based alloys regulated intimal hyperplasia using a macrophage-VSMC coculture system in vitro.

We present the following article in accordance with the Materials Design Analysis Reporting (MDAR) checklist (available at https://dx.doi.org/10.21037/atm-21-1375).

\section{Methods}

\section{FDBM extract preparation}

The composition of the $\mathrm{Mg}-\mathrm{Nd}-\mathrm{Zn}-\mathrm{Zr}$ alloy ingot (denoted as JDBM), which was especially designed for vascular stents, has been described in previous studies. The composition of the biodegradable JDBM alloy is as follows (mass percent): Mg: $>97 \%$, Nd: $2.1 \%$, Zn: $0.21 \%$, Zr: 0.5\%, Mn: 0.009\%, Si: $0.006 \%$, Cu: $0.005 \%$, Fe: $0.002 \%$ (29-32). JDBM discs (18 $\mathrm{mm}$ in diameter and $2.0 \mathrm{~mm}$ in height) were immersed in an ultrasonic cleaning bath with ethanol and acetone for $10 \mathrm{~min}$ and then sterilized by exposure to ultraviolet light for $1 \mathrm{~h}$ before use. JDBM extracts were prepared according to the ISO 10993 guidelines. Briefly, JDBM discs were immersed in DMEM (High glucose, Gibco, USA) supplemented with $10 \%$ fetal bovine serum (FBS) (Gibco, USA) and $1 \%$ penicillin-streptomycin (PS) (HyClone, USA) with a surface area/volume ratio of $1.25 \mathrm{~cm}^{2} / \mathrm{mL}$ at $37{ }^{\circ} \mathrm{C}$ and $5 \% \mathrm{CO}_{2}$ for $72 \mathrm{~h}$. After that, the extracts were then harvested, filtered by a $0.2 \mu \mathrm{m}$ filter, and stored at $4{ }^{\circ} \mathrm{C}(30)$. To avoid the cytotoxicity of full-strength extract (30), the JDBM extracts were further diluted to $15 \%$ and $5 \%$ with fresh complete DMEM supplemented with $10 \%$ FBS (Gibco, USA) and 1\% PS (HyClone, USA). Subsequently, we detected the concentration of $\mathrm{Mg}$ ions from JDBM by inductively coupled plasma atomic emission spectrometry (ICP-AES, Perkin-Elmer Optima 2000, USA), and the concentration of $\mathrm{Mg}$ ions from the $15 \%$ JDBM extract was approximately $150 \mathrm{ppm}$ (ppm equals $1 \mathrm{mg}$ of substance per liter, $\mathrm{mg} / \mathrm{L}$ ). As the molecular weight of $\mathrm{Mg}$ is $24 \mathrm{~g} / \mathrm{mol}$, we prepared $\mathrm{MgCl}_{2}$ solution at $6 \mathrm{mM}$ of the final $\mathrm{Mg}$ ion concentration similar to that of the $15 \%$ extract $(150 \mathrm{mg} / \mathrm{L})$. Then, $2 \mathrm{mM} \mathrm{MgCl}$ solutions were prepared to simulate the $\mathrm{Mg}$ ion concentration of the $5 \%$ extract $(50 \mathrm{mg} / \mathrm{L})$. Finally, the $\mathrm{Mg}, \mathrm{Nd}, \mathrm{Zn}$, and $\mathrm{Zr}$ ion concentrations were determined by ICP-AES, and $\mathrm{pH}$ of the complete DMEM medium (control), JDBM extracts, and $\mathrm{MgCl}_{2}$ solutions were determined by a $\mathrm{pH}$ detector (PB-10, Sartorius, Germany). ICP-AES is a method of emission spectroscopy that excites atoms and ions with a plasma, causing it to emit electromagnetic radiation at wavelengths characteristic of a particular element. For $\mathrm{pH}$ detection, the $\mathrm{pH}$ meter was calibrated with $\mathrm{pH}$ buffer solutions (4.00 and 6.86) before detecting the $\mathrm{pH}$ values of the solutions.

\section{Cell culture and treatments}

RAW264.7 macrophage-like cells were cultured in DMEM complete medium supplemented with $10 \%$ FBS and $1 \%$ PS in a humidified $5 \% \mathrm{CO}_{2}$ incubator at $37^{\circ} \mathrm{C}$. To study the effects of JDBM extracts and $\mathrm{MgCl}_{2}$ solutions on macrophages, cells were activated by lipopolysaccharide (LPS, $1 \mathrm{mg} / \mathrm{mL}$, Invitrogen, USA) for $6 \mathrm{~h}$ and then washed with phosphate-buffered saline (PBS) 3 times. After that, the activated RAW264.7 cells were treated with or without $5 \%$ extract, $15 \%$ extract, $2 \mathrm{mM} \mathrm{MgCl}$, or $6 \mathrm{mM} \mathrm{MgCl} 2$ for another $72 \mathrm{~h}$. To prepare conditioned media (CM), at the end of the culture time, the supernatants of each group were sequentially collected, centrifuged for $5 \mathrm{~min}$ at 1,500 rpm, mixed with fresh DMEM complete medium at a ratio of $1: 1$, and stored at $-80{ }^{\circ} \mathrm{C}$ until use. A7r5 VSMCs were cultured in different CMs for another $72 \mathrm{~h}$ before a series of functional assays.

\section{Cell proliferation and viability assays}

The cell counting kit-8 (CCK-8) assay (Dojindo, Japan) evaluated cell proliferation and viability according to the manufacturer's instructions. Briefly, RAW264.7 cells or A7r 5 cells were seeded into 96-well plates and then treated as described above. Then, the cell media culture was removed, and the cells were washed with PBS twice. After that, $100 \mu \mathrm{L}$ of DMEM containing $10 \%$ CCK- 8 solution (Dojindo, Kumamoto, Japan) was added to each well, followed by incubation for $3 \mathrm{~h}$ in a humidified $5 \% \mathrm{CO}_{2}$ incubator at $37{ }^{\circ} \mathrm{C}$. Finally, the absorbance was measured in a microplate reader (BioTek, Winooski, VT, USA) at a $450 \mathrm{~nm}$ test wavelength.

\section{Apoptosis and necrosis detection by flow cytometry}

Annexin V-FITC and propidium iodide (PI) (BD, USA) were used to measure cell apoptosis and necrosis according to the manufacturer's instructions. The target protein of Annexin V-FITC is Annexin V, and PI is a fluorescent dye that binds to DNA. The cells were treated, harvested, and washed with cold PBS. Then, the cells were suspended 
in $1 \times$ Annexin binding buffer and stained with Annexin V-FITC and PI for $15 \mathrm{~min}$ in the dark at room temperature. Finally, apoptotic and necrotic cells were analyzed by flow cytometry (FACS, Canto II, BD, USA). For the gating strategies, forward versus side scatter (FSC vs. SSC) gating was used to identify cells of interest based on size and granularity (complexity), then a two-parameter density plot was used to distinguish specific cell populations by creating a plot of Annexin V vs. PI. Each quadrant represented a specific cell population: (I) Annexin V-/PI-: living cells; (II) Annexin V+/PI-: early apoptotic cells; (III) Annexin V+/PI+: late apoptotic cells; (IV) Annexin V-/PI+: necrotic cells.

\section{Cell cycle analysis by flow cytometry}

A7r5 cells were harvested after being cultured in different CMs for $72 \mathrm{~h}$. The cells were washed once with cold PBS, fixed in ice-cold $70 \%$ ethanol, and then stored at $-20{ }^{\circ} \mathrm{C}$ overnight. After that, the cells were washed with PBS, suspended in $500 \mu \mathrm{L}$ of PBS containing $100 \mu \mathrm{g} / \mathrm{mL}$ RNase A and $150 \mu \mathrm{g} / \mathrm{mL}$ PI (Beyotime, China), and incubated at $4{ }^{\circ} \mathrm{C}$ for $30 \mathrm{~min}$. Finally, the cells were collected and analyzed by FACS (Canto II, BD, USA).

\section{Transwell migration and wound healing assays}

For the transwell migration assay, A7r5 cells were seeded at a density of $5 \times 10^{4} / \mathrm{mL}$ in $100 \mu \mathrm{L}$ of serum-free DMEM in the upper chamber of the inserts $(8 \mu \mathrm{m}$ pore size, Corning, USA), and different CMs were added to the lower chambers. After $8 \mathrm{~h}$ of incubation in a humidified $5 \% \mathrm{CO}_{2}$ incubator at $37^{\circ} \mathrm{C}$, the cells on the upper side of the insert were removed, and cells on the bottom side were washed with PBS, fixed with $4 \%$ paraformaldehyde for $10 \mathrm{~min}$, and stained with hematoxylin and eosin. Finally, images were captured, and the cell number was determined by counting 5 random microscopic fields $(\times 200)$.

For the wound healing assay, A7r5 cells were seeded at a density of $5 \times 10^{5}$ cells/well in a 6-well plate. After incubation for $24 \mathrm{~h}$, adherent A7r5 cells were scratched with pipette tips and washed with PBS. Different CMs were added to the cells and incubated for $48 \mathrm{~h}$, and then NIH ImageJ 1.46 software was used to quantify the migration ability of cells by subtracting the scratch distance at $0 \mathrm{~h}$ from the area at $48 \mathrm{~h}$.

\section{Real-time quantitative PCR (RT-qPCR)}

Total RNA was isolated using TRIzol reagent
(Invitrogen, USA), and cDNA was synthesized with a ReverTra Ace qPCR RT kit (Toyobo, Japan) according to the manufacturer's instructions. Subsequently, qPCR was performed with SYBR Green real-time PCR master mix (Toyobo, Japan). The quantity and quality of RNA were determined by NanoDrop 2000 spectrophotometer (Thermo Fisher Scientific, USA). The expression levels of target genes were evaluated using the $\Delta \Delta \mathrm{Ct}$ method and were normalized to GAPDH. The primer sequences of the target genes are listed in Table S1.

\section{Statistical analysis}

The data are presented as the mean \pm standard deviation (SD). Statistical analysis was performed using the MannWhitney U test or one-way ANOVA with Tukey's honestly significant difference (HSD) test and SPSS software. The differences were considered significant at a $\mathrm{P}$ value $<0.05$.

\section{Results}

The cytotoxic effects of $\mathcal{F D B M}$ extracts and $\mathrm{MgCl}_{2}$ solutions on macrophages

Since $\mathrm{Mg}$ ions are the main degradation product of $\mathrm{Mg}$ based alloys, we investigated the role of $\mathrm{Mg}$ ions from JDBM in this study by preparing $15 \%$ and $5 \%$ JDBM extracts and $\mathrm{MgCl}_{2}$ solutions with equivalent $\mathrm{Mg}$ ion concentrations of 6 and $2 \mathrm{mM}$, respectively (Figure $1 A$ ). The control group, which was comprised of a DMEM complete medium, also contained a low concentration of $\mathrm{Mg}$ (Figure $1 A$ ), providing a basal $\mathrm{Mg}$ level for cells.

Then, we evaluated the cytotoxic effects of JDBM extracts and $\mathrm{MgCl}_{2}$ solutions on macrophages. After incubation for $72 \mathrm{~h}$, the cell viability and percentages of apoptotic and necrotic cells were similar between groups, indicating that neither JDBM extracts nor $\mathrm{MgCl}_{2}$ solutions exerted cytotoxic effects on macrophages (Figure 1B,1C).

\section{The effects of $\mathcal{F D B M}$ extracts and $\mathrm{MgCl}_{2}$ solutions on the polarization of macrophages}

After the macrophages were treated with LPS for $6 \mathrm{~h}$, the activated macrophages were incubated with JDBM extracts and $\mathrm{MgCl}_{2}$ solutions for another $72 \mathrm{~h}$. As shown in Figure $2 A, 2 B$, compared with the control treatment, the $15 \% \mathrm{JDBM}$ extract and $6 \mathrm{mM} \mathrm{MgCl}$ solution significantly downregulated the expression of proinflammatory genes, 
A

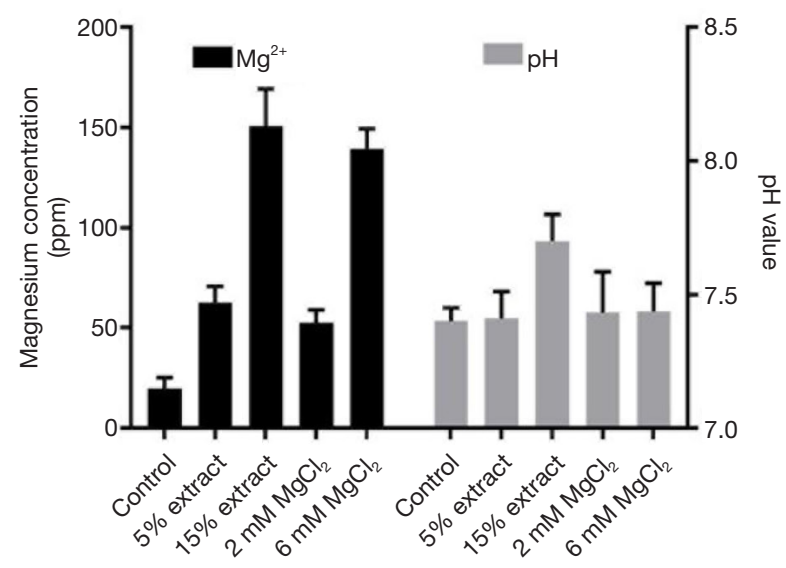

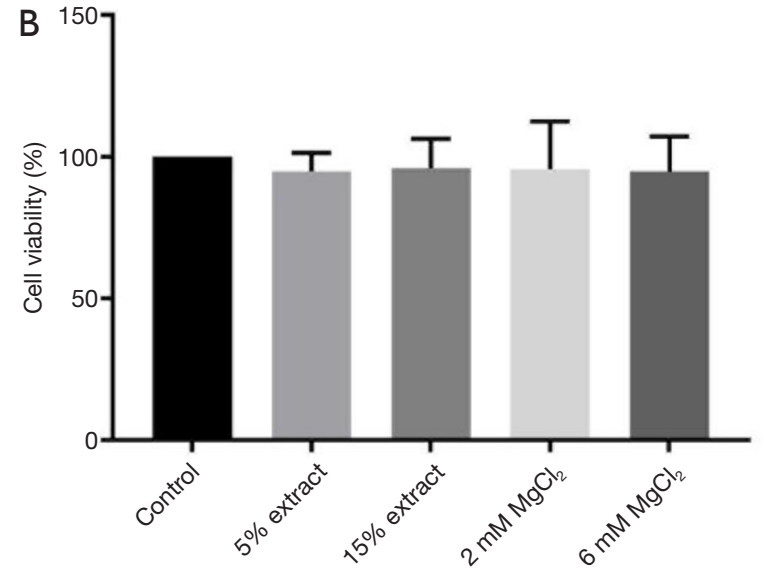

C

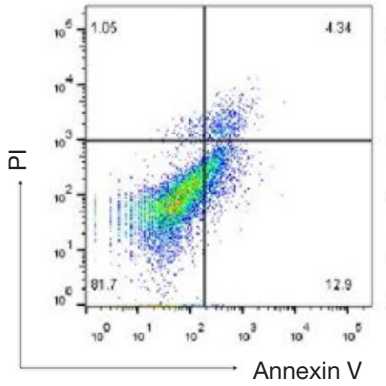

Control

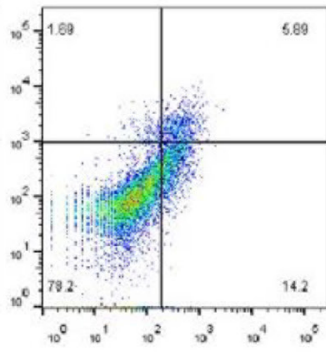

$5 \%$ extract

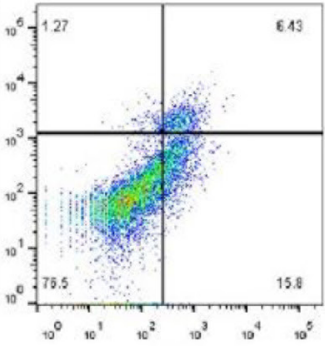

$15 \%$ extract

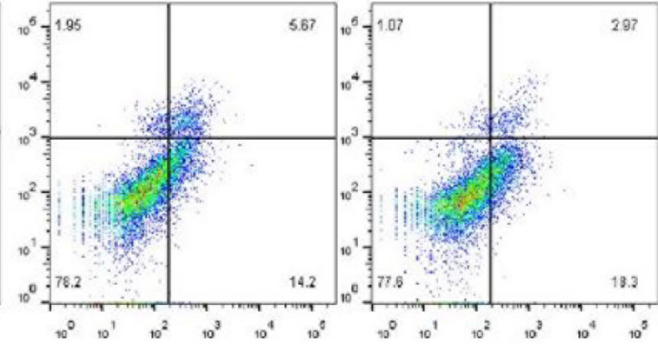

$2 \mathrm{mM} \mathrm{MgCl}_{2}$

$6 \mathrm{mM} \mathrm{MgCl}{ }_{2}$

Figure 1 The cytotoxicity of JDBM extracts and $\mathrm{MgCl}_{2}$ solutions on RAW264.7 cells. (A) The magnesium concentration and pH of JDBM extracts and $\mathrm{MgCl}_{2}$ solutions were determined by inductively coupled plasma atomic emission spectrometry (ICP-AES) and a pH detector, respectively, and each experiment was repeated 3 times. After incubation with JDBM extracts or $\mathrm{MgCl}_{2}$ solutions for 3 days, the viability of RAW264.7 cells was determined by the cell counting kit-8 (CCK-8) assay (n=8), (B) and the percentages of apoptotic and necrotic cells were determined by flow cytometry. Forward versus side scatter (FSC vs. SSC) gating was used to identify cells of interest based on size and granularity (complexity), then a two-parameter density plot was used to distinguish specific cell populations by creating a plot of Annexin $\mathrm{V} v$ s. propidium iodide (PI). Each quadrant represents a specific cell population: (I) Annexin V-/PI-: living cells; (II) Annexin V+/PI-: early apoptotic cells; (III) Annexin V+/PI+: late apoptotic cells; (IV) Annexin V-/PI+: necrotic cells (C). Statistical analysis was performed by oneway ANOVA, and $\mathrm{P}$ value $<0.05$ was considered as significant.

such as Tnfa and $I l-6$, while the $5 \%$ JDBM extract and 2 $\mathrm{mM} \mathrm{MgCl} 2$ solution significantly inhibited Tnfa but not Il-6 expression. Moreover, the $15 \%$ JDBM extract and $6 \mathrm{mM}$ $\mathrm{MgCl}_{2}$ solution significantly downregulated the expression of M1-associated genes (iNOS and Cd86) and significantly upregulated the expression of M2-associated genes (Cd163 and $C d 206$ ). However, the $5 \%$ JDBM extract and $2 \mathrm{mM}$ $\mathrm{MgCl}_{2}$ solution only significantly regulated some M1and M2-related genes (iNOS and Cd163), and the expression of $C d 86$ and $C d 206$ was similar in the different groups (Figure $2 C-2 F)$.

\section{The effects of $7 D B M$ extracts and $\mathrm{MgCl}_{2}$ solutions on the expression of genes related to VSMC phenotypic switching, migration, and proliferation in macrophages}

Furthermore, we evaluated the effect of JDBM extracts and $\mathrm{MgCl}_{2}$ solutions on the expression of genes related to VSMC phenotypic switching, migration, and proliferation in macrophages. The results showed that the $15 \%$ JDBM extract and $6 \mathrm{mM} \mathrm{MgCl}$ solution could significantly downregulate the expression of matrix metalloproteinases (Mmp-2 and Mmp-9), which are regulators of extracellular 

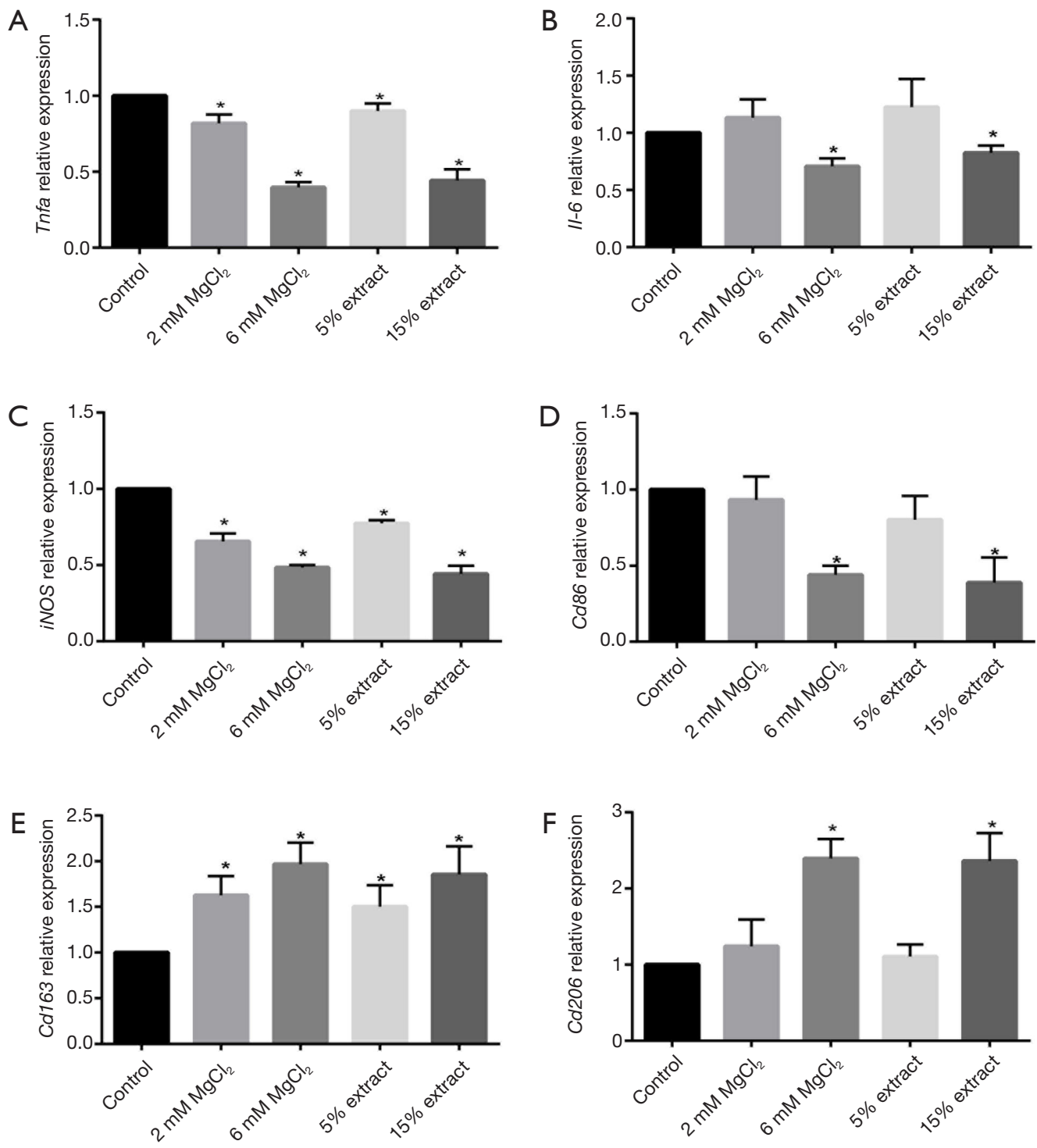

Figure 2 The effects of JDBM extracts and $\mathrm{MgCl}_{2}$ solutions on proinflammatory cytokine expression and the polarization of RAW264.7 cells. After treatment with JDBM extracts and $\mathrm{MgCl}_{2}$ solutions for 3 days, the expression of Tnfa (A) and Il-6 (B) in RAW264.7 cells was determined by quantitative reverse transcription PCR (RT-qPCR). M1 macrophage-associated markers (C,D) and M2 macrophageassociated markers (E,F) were also measured by RT-qPCR. * $\mathrm{P}<0.05$ vs. the control group. Error bars represent the standard deviation (SD) of quadruplicate experiments. Statistical analysis was performed by the Mann-Whitney $\mathrm{U}$ test, and $\mathrm{P}$ value $<0.05$ was considered as significant.

matrix (ECM) composition and facilitate the migration of VSMCs (Figure 3A,3B). In addition, these treatments significantly decreased the expression of plateletderived growth factor subunit B $(P d g f b)$, transforming growth factor beta $(T g f b)$, and vascular cell adhesion molecule 1 (Vcam-1), all of which have been reported to play roles in promoting VSMC phenotypic switching, proliferation, and migration (Figure 3C-3E). Unexpectedly, it was interesting to note that the JDBM extracts and $\mathrm{MgCl}_{2}$ solutions with low but not high concentrations of $\mathrm{Mg}^{2+}(2$ $\mathrm{mM})$ could increase the expression of vascular endothelial growth factor (Vegf) in macrophages (Figure $3 F$ ). This is in line with previous studies which showed the interaction between M2 macrophages and VEGF. On the one hand, 

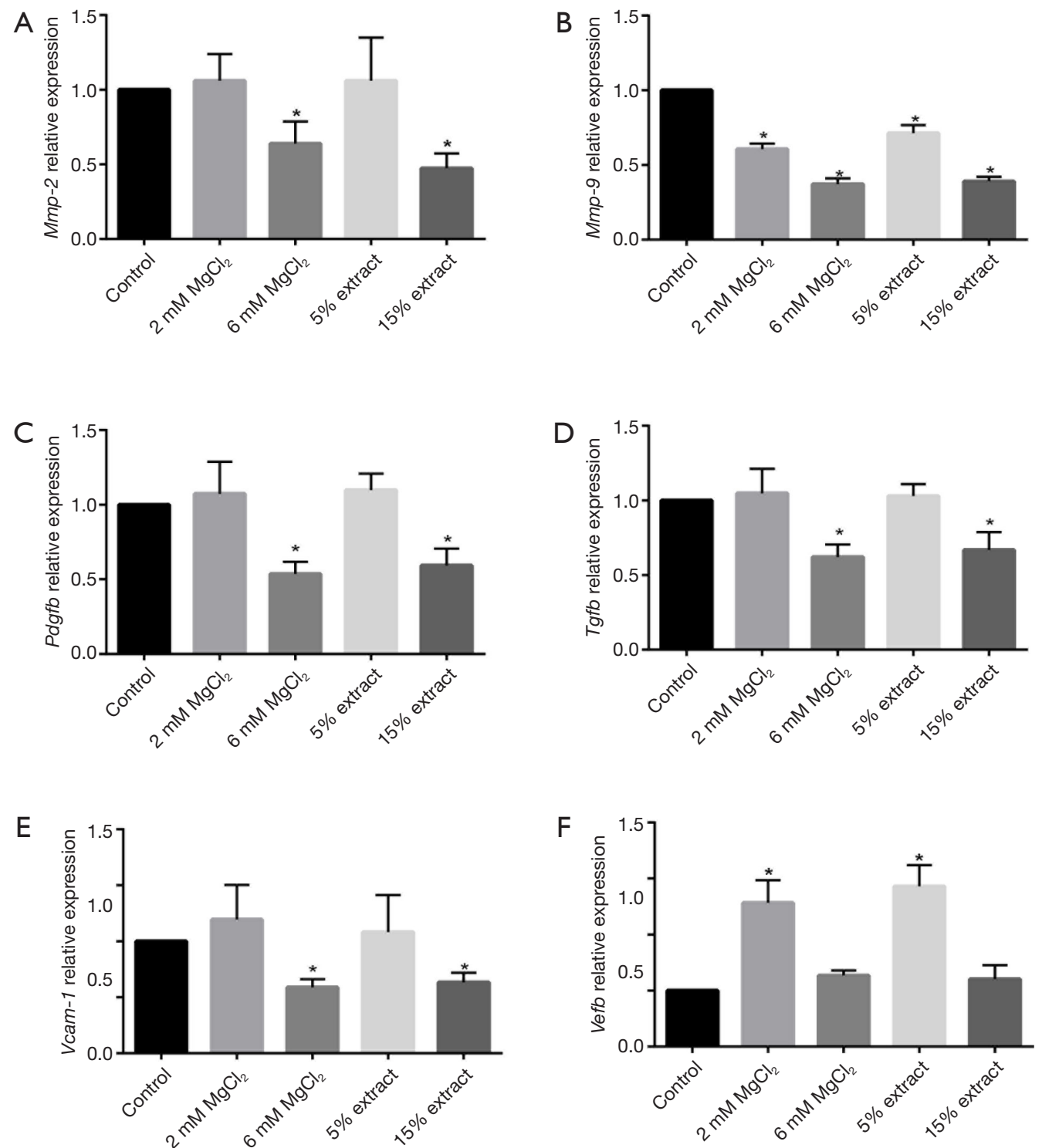

Figure 3 The effects of JDBM extracts and $\mathrm{MgCl}_{2}$ solutions on the expression of genes related to vascular smooth muscle cell (VSMC) phenotypic switching, migration, and proliferation in RAW264.7 cells. After treatment with JDBM extracts and $\mathrm{MgCl}_{2}$ solutions for 3 days, gene expression was determined by quantitative reverse transcription PCR (RT-qPCR) (A-F). ${ }^{*} \mathrm{P}<0.05$ vs. the control group. Error bars represent the standard deviation (SD) of quadruplicate experiments. Statistical analysis was performed by the Mann-Whitney $\mathrm{U}$ test, and $\mathrm{P}$ value $<0.05$ was considered as significant.

M2 macrophages could secrete VEGF to stimulate angiogenesis, while on the other hand, VEGF contributes to macrophage recruitment and M2 polarization (33-36).

\section{The cytotoxic effects of CMs on VSMCs}

To study the effects of JDBM on the function of VSMCs via macrophage-mediated immunoregulation, CMs were obtained from macrophages to establish an indirect VSMCmacrophage coculture system. A7r5 cells were cultured in different CMs for $72 \mathrm{~h}$, and the cytotoxic effects of the CMs were determined. The results showed that the percentages of apoptotic and necrotic cells and cell cytotoxicity were similar between groups (Figure $4 A, 4 B$ ). The amount of spontaneous apoptosis determined by the $\mathrm{Bax} / \mathrm{Bcl}$ 2 ratio was also similar between groups (Figure $4 C-4 E$ ). 


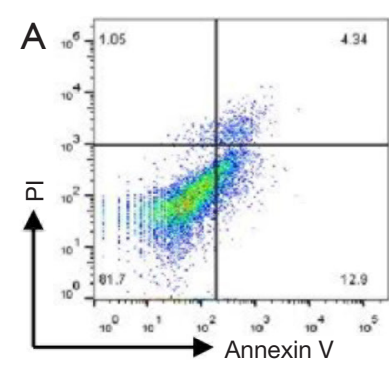

Control

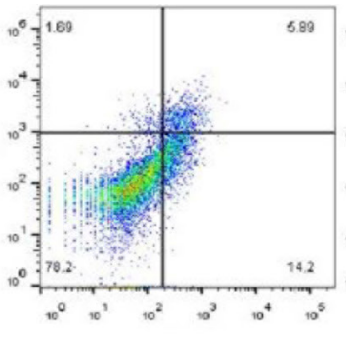

$5 \%$ extract

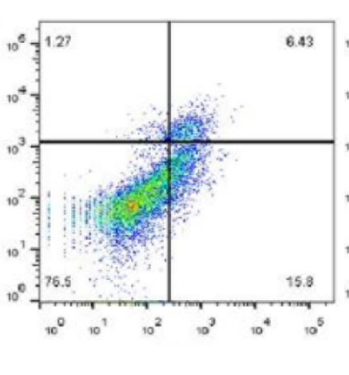

$15 \%$ extract

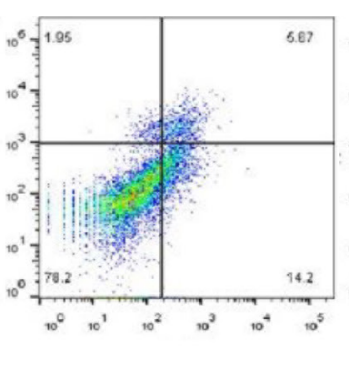

$2 \mathrm{mM} \mathrm{MgCl}_{2}$

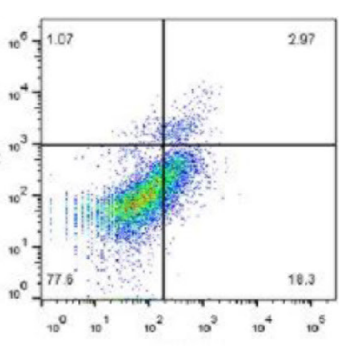

$6 \mathrm{mM} \mathrm{MgCl}_{2}$

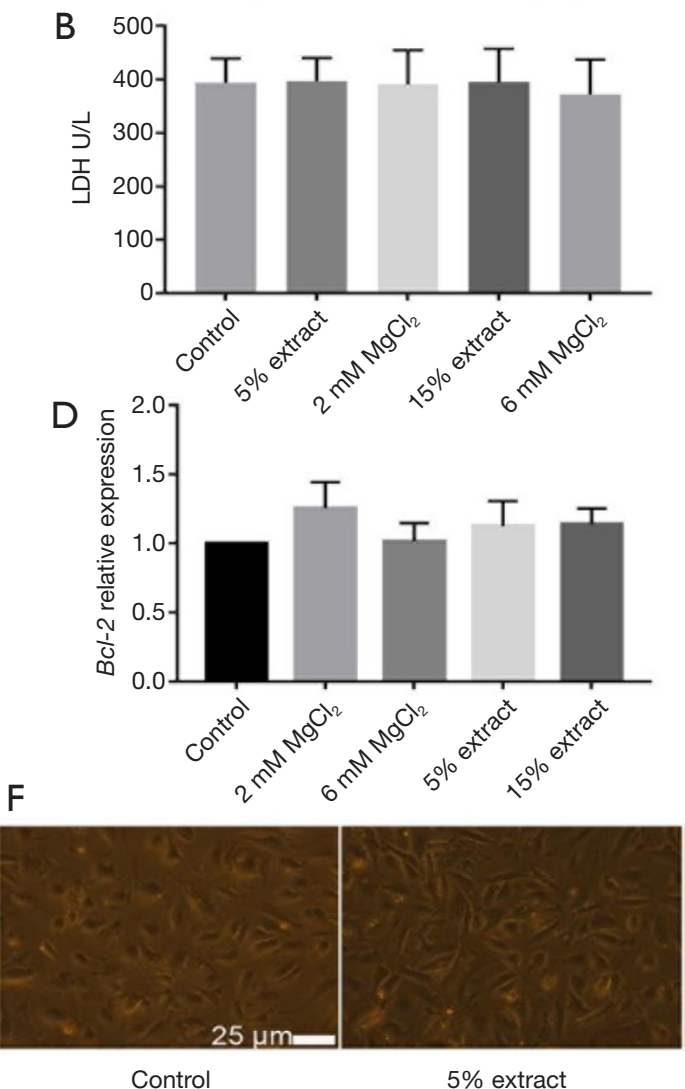

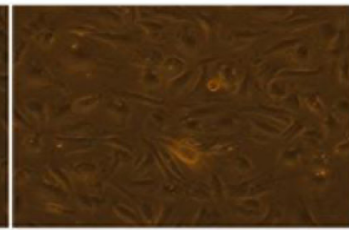

$15 \%$ extract

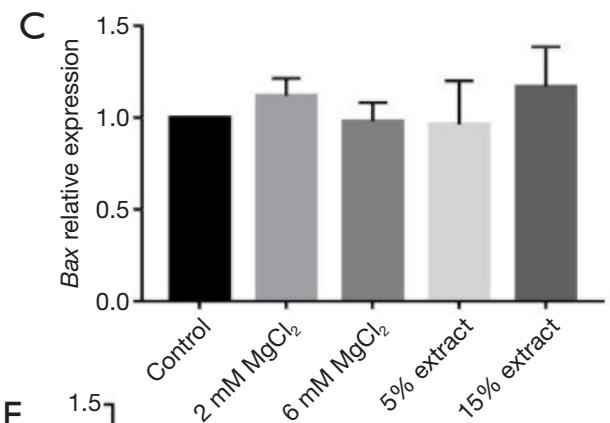

E

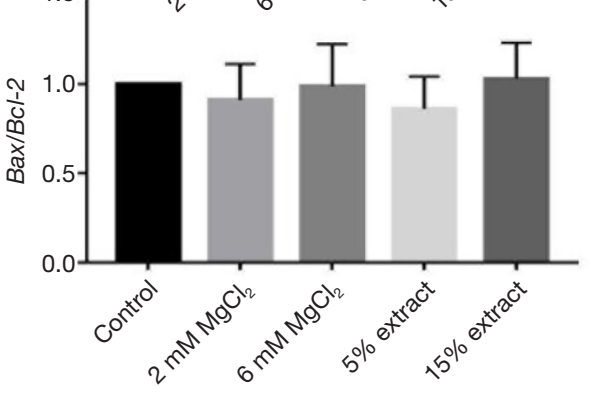

Figure 4 The biocompatibility of conditioned medias (CMs) with A7r5 cells. CMs, which were derived from RAW264.7 cells treated with JDBM extracts or $\mathrm{MgCl}_{2}$ solutions, were added to A7r5 cells and incubated for $72 \mathrm{~h}$. (A) The percentages of apoptotic and necrotic A7r5 cells were determined by flow cytometry. Each quadrant represents a specific cell population: (I) Annexin V-/PI-: living cells; (II) Annexin V+/PI-: early apoptotic cells; (III) Annexin V+/PI+: late apoptotic cells; (IV) Annexin V-/PI+: necrotic cells. (B) The cytotoxicity of cells was analyzed by lactate dehydrogenase $(\mathrm{LDH})$ assays $(\mathrm{n}=3)(\mathrm{B})$, and the ratio of $\mathrm{Bax} / \mathrm{Bcl}-2$ was determined by quantitative reverse transcription PCR (RT-qPCR). Error bars represent the standard deviation (SD) of quadruplicate experiments (C-E). (F) The morphology of A7r5 cells was observed by microscopy. Scale bar $=25 \mu \mathrm{m}$. Statistical analysis for LDH assays was performed by one-way ANOVA, and statistical analysis for RT-qPCR was performed by the Mann-Whitney $\mathrm{U}$ test. P value $<0.05$ was considered as significant.

Furthermore, the CMs from different groups did not affect the cellular morphology of VSMCs (Figure 4F). These results indicated that none of the CMs exerted cytotoxic effects on VSMCs and could be used in further studies.

\section{The effects of CMs on the cell cycle and proliferation of VSMCs}

Increased proliferation has been reported to be a 

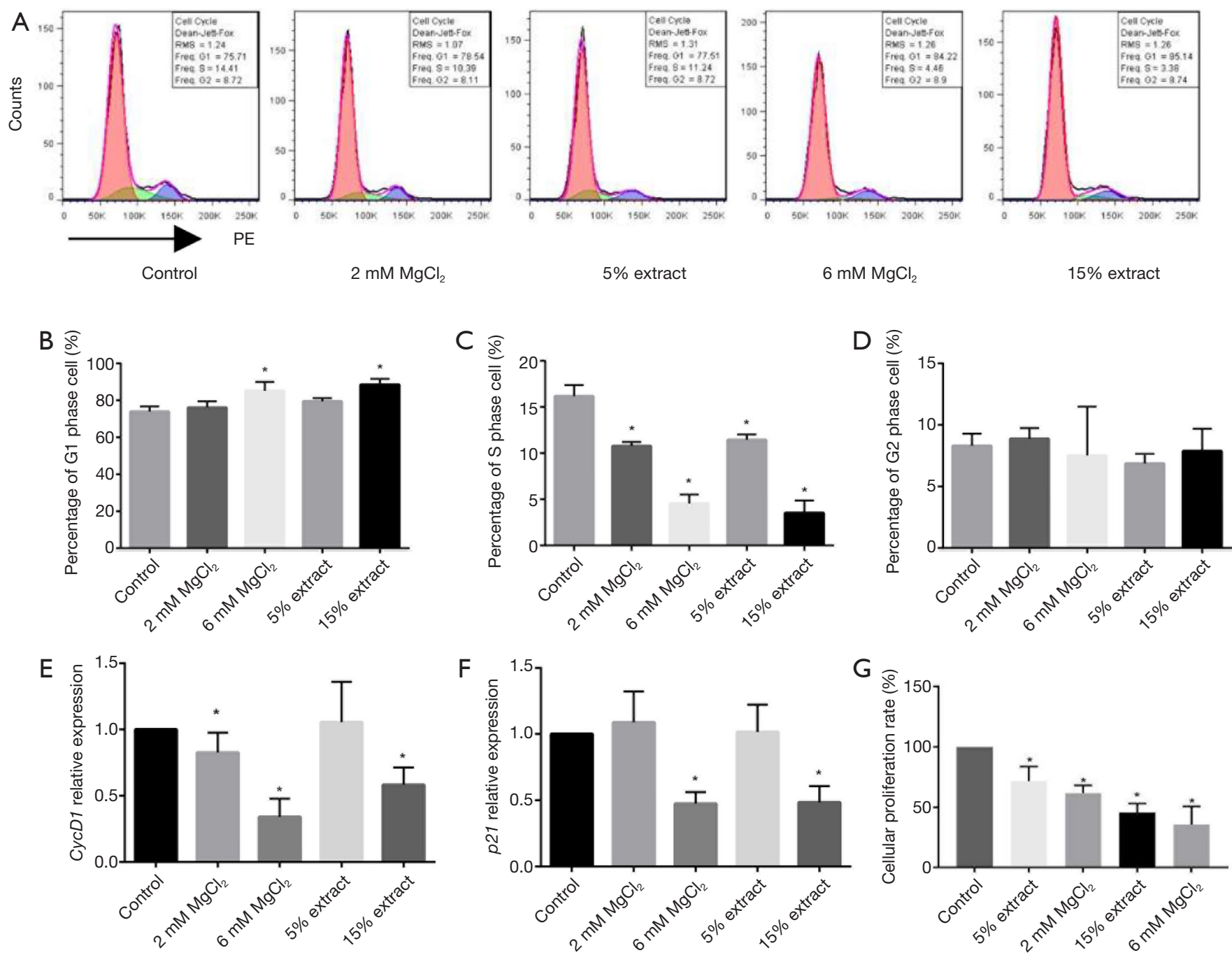

Figure 5 The effects of conditioned medias (CMs) on the proliferation of A7r5 cells. A7r5 cells were treated with different CMs for 72 h. The cell cycle was analyzed by flow cytometry $(n=3)(A-D)$. Cell cycle proteins were measured with quantitative reverse transcription PCR (RT-qPCR), and error bars represent the standard deviation (SD) of triplicate experiments (E,F). The cellular growth rate was analyzed by the cell counting kit-8 (CCK-8) assay $(\mathrm{n}=8)(\mathrm{G}) .{ }^{*} \mathrm{P}<0.05$ vs. the control group. Statistical analysis for the cell cycle assay was performed by one-way ANOVA, and statistical analysis for RT-qPCR and the CCK-8 assay was performed by the Mann-Whitney U test. P value $<0.05$ was considered as significant.

characteristic of VSMC switching to a proinflammatory phenotype. Therefore, we evaluated the effect of different CMs on the cell cycle and proliferation of VSMCs. As shown in Figure 5A-5F, compared with the control group CM, CMs from macrophages treated with high concentrations of JDBM extract and $\mathrm{MgCl}_{2}$ solutions induced G1-phase cell cycle arrest and the loss of $p 21$ and Cyclin D1. In addition, all CMs from macrophages treated with JDBM extracts and $\mathrm{MgCl}_{2}$ solutions significantly decreased the proportions of VSMCs in S phase. Not surprisingly, as shown in Figure $5 G$, compared with the control group CM, all CMs from macrophages treated with JDBM extracts and $\mathrm{MgCl}_{2}$ solutions significantly inhibited the proliferation of VSMCs in a dose-dependent manner.

\section{The effects of CMs on the migration of VSMCs}

Next, a transwell migration assay was used to study the effects of CMs on the migration of VSMCs. The results 


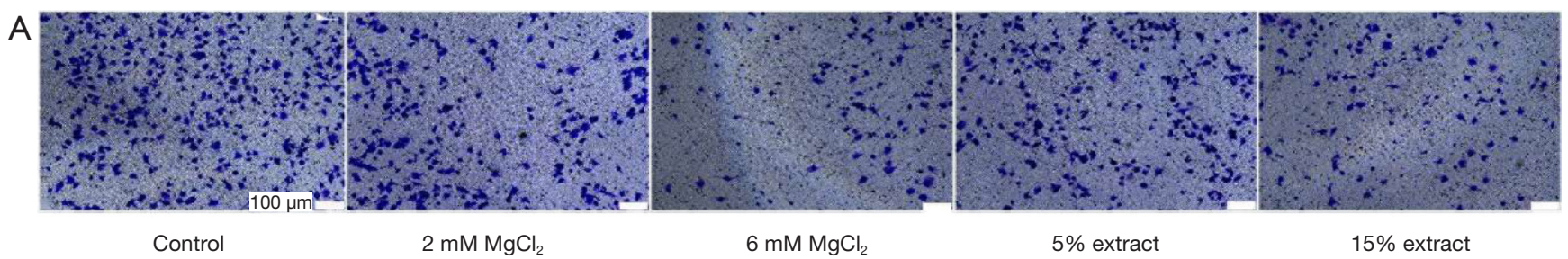

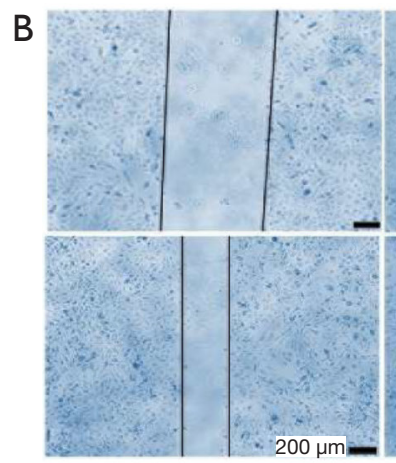

Control

$2 \mathrm{mM} \mathrm{MgCl}_{2}$

$6 \mathrm{mM} \mathrm{MgCl}_{2}$

$5 \%$ extract

$15 \%$ extract

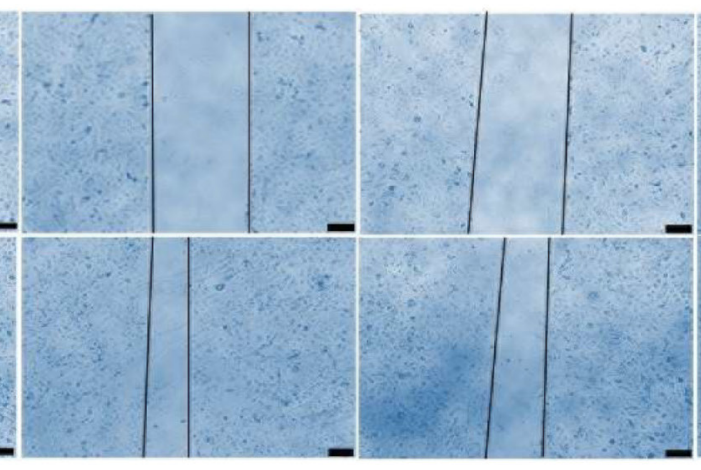

$2 \mathrm{mM} \mathrm{MgCl}{ }_{2}$

$5 \%$ extract

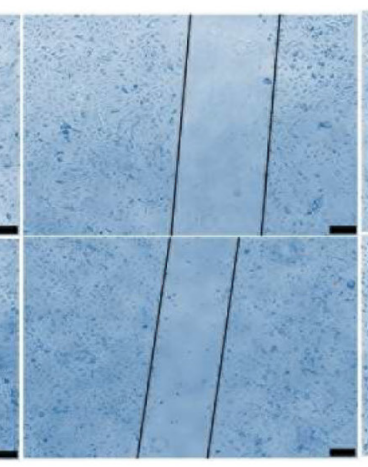

$6 \mathrm{mM} \mathrm{MgCl}_{2}$

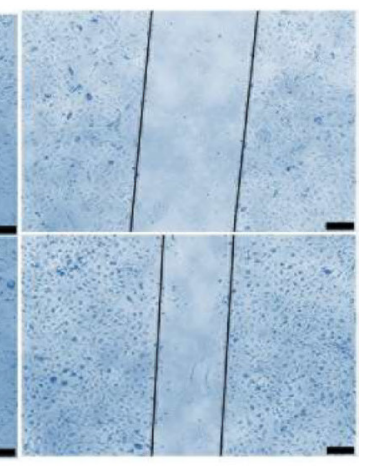

$15 \%$ extract
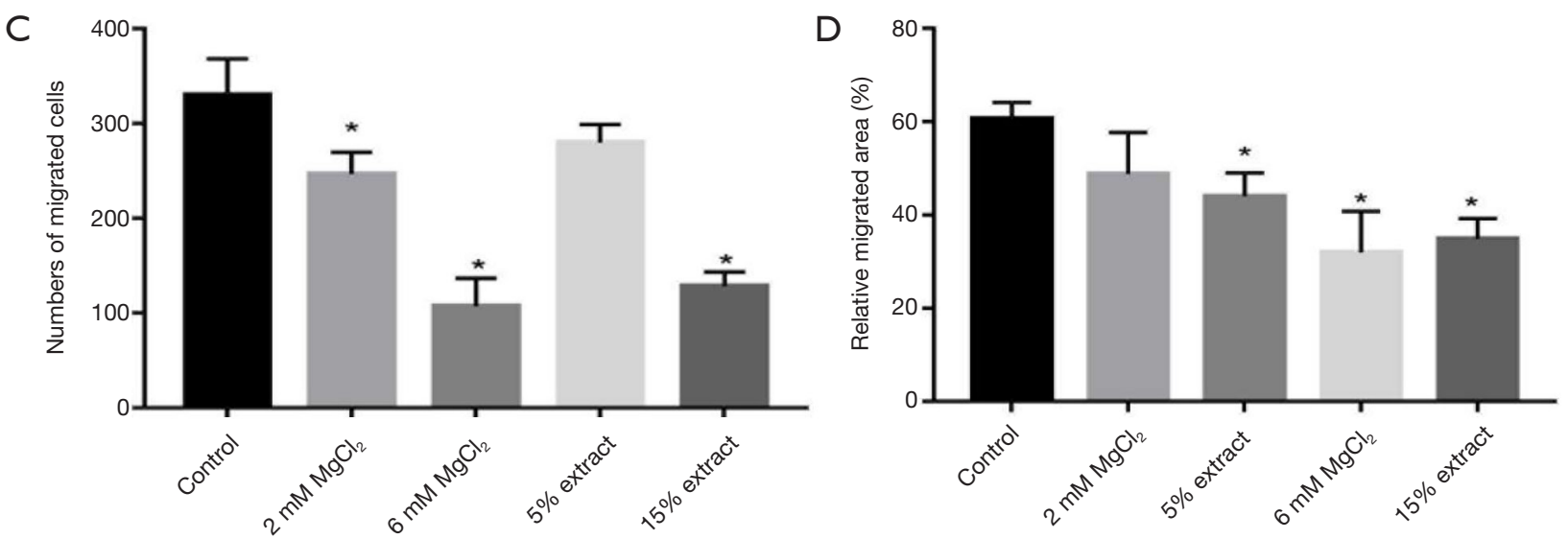

Figure 6 The effects of conditioned medias (CMs) on the migration of A7r5 cells. (A,C) A7r5 cells were seeded on transwell plates with different CMs for $8 \mathrm{~h}$, and the results were observed by microscopy. Scale bar =100 $\mu \mathrm{m}$. (B,D) The cells were scratched, and different CMs were added and incubated for $48 \mathrm{~h}$ to observe the migration rate by microscopy. Scale bar $=200 \mu \mathrm{m}$. The data are presented as the mean \pm standard deviation (SD) $(\mathrm{n}=3)$. ${ }^{*} \mathrm{P}<0.05$ vs. the control group. Statistical analysis was performed by one-way ANOVA, and $\mathrm{P}$ value $<0.05$ was considered as significant.

showed that, compared with the control group CM, CMs from macrophages treated with JDBM extracts and $\mathrm{MgCl}_{2}$ solutions significantly inhibited the migration of VSMCs in a dose-dependent manner (Figure $6 A$ ). The wound healing assay (Figure $6 B$ ) further confirmed these results. Figure $6 C, 6 D$ show the statistical analysis data. These results suggested that JDBM extracts and $\mathrm{MgCl}_{2}$ solutions could significantly inhibit the migration of VSMCs via macrophage-mediated immunoregulation.

\section{The effects of CMs on the polarization of VSMCs}

In addition to the effects of different $\mathrm{CMs}$ on proliferation and migration, the effects of different CMs on the polarization of VSMCs were also evaluated by measuring the gene expression of VSMC contractile markers, including sm-MHC, $\alpha$-Sma, Myoc, and Sm22 $\alpha$. The results showed that compared with the control group CM, CMs from macrophages treated with JDBM extracts and 

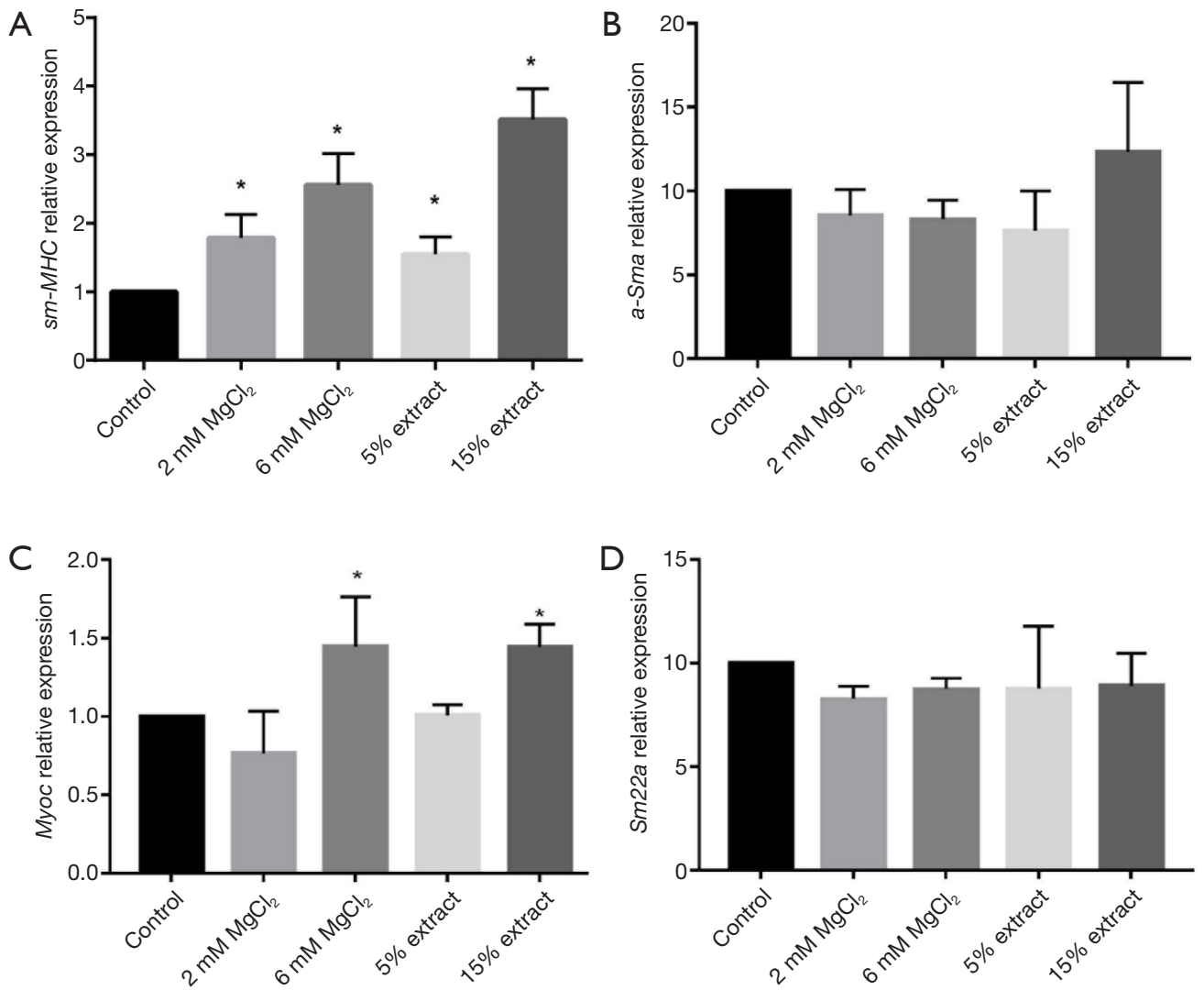

Figure 7 The effects of conditioned medias (CMs) on the polarization of A7r5 cells. A7r5 cells were treated with CMs for 72 h, then phenotype-related markers were determined by quantitative reverse transcription PCR (RT-qPCR). Error bars represent the standard deviation (SD) of quadruplicate experiments. ${ }^{*} \mathrm{P}<0.05$ vs. the control group. Statistical analysis was performed by one-way ANOVA, and $\mathrm{P}$ value $<0.05$ was considered as significant.

$\mathrm{MgCl}_{2}$ solutions significantly upregulated the expression of $s m-M H C$ and Myoc. However, the expression of $\alpha-S m a$ and $S m 22 \alpha$ was similar in the different groups (Figure $7 A-7 D$ ). These results indicated that JDBM extracts and $\mathrm{MgCl}_{2}$ solutions could significantly inhibit the phenotypic switching of VSMCs to a proinflammatory phenotype via macrophage-mediated immunoregulation.

\section{Discussion}

Restenosis after PCI, which is mainly due to intimal hyperplasia, remains a significant clinical problem, such as in coronary artery bypass graft failure $(21,37)$. Intimal hyperplasia is mainly caused by the proliferation and migration of VSMCs and excessive inflammation due to activated macrophages (25). Biodegradable $\mathrm{Mg}$-based alloys, which have been reported to be promising candidates for cardiovascular stents, were shown to reduce neointima formation in vivo $(18,38)$. In contrast, in vitro studies showed that $\mathrm{Mg}$ ions could promote the proliferation and migration of VSMCs (14). These seemingly contradictory results suggest the presence of complex regulatory effects on the phenotypic change in VSMCs induced by Mgbased alloys in vivo. This study aimed to elucidate the mechanisms underlying the seemingly contradictory results from in vivo and in vitro studies. We simulated the physiological environment using a macrophageVSMC coculture system in vitro and demonstrated that JDBM extract could affect VSMC phenotypic switching, migration, and proliferation by macrophage-mediated immunoregulation, in which $\mathrm{Mg}$ ions play a vital role. Three major results were observed: (I) JDBM extracts and $\mathrm{MgCl}_{2}$ solutions significantly alleviated the inflammatory response induced by LPS in macrophages by reversing the polarization of proinflammatory M1 macrophages to an anti-inflammatory M2 phenotype; (II) JDBM extracts 


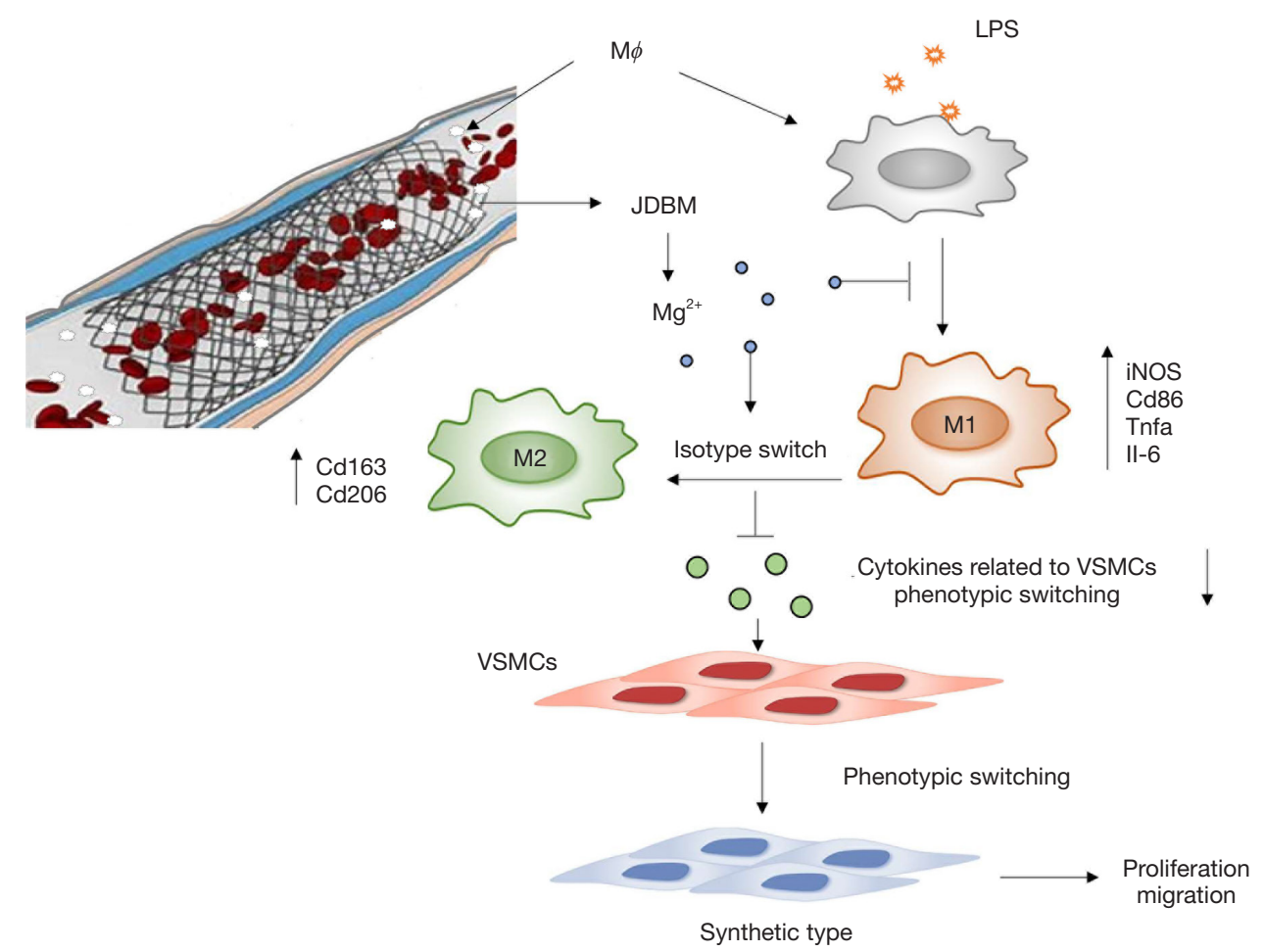

Figure 8 Schematic illustration of the potential mechanism underlying the effect of JDBM on vascular smooth muscle cells (VSMCs) through macrophage-mediated immunoregulation. Magnesium reverses the lipopolysaccharide (LPS)-induced polarization of M1type macrophages to M2-type macrophages and inhibits the expression of genes related to VSMC phenotypic switching, migration, and proliferation in macrophages, further inhibiting the phenotypic switching, migration, and proliferation of VSMCs.

and $\mathrm{MgCl}_{2}$ solutions significantly decreased the expression of genes related to VSMC phenotypic switching, migration, and proliferation in macrophages; and (III) CMs derived from LPS-activated macrophages treated with JDBM extracts or $\mathrm{MgCl}_{2}$ solutions inhibited VSMC proliferation, migration, and phenotypic switching from a contractile phenotype to a proinflammatory phenotype (Figure 8).

Increasing evidence has suggested the vital role of inflammation in the initiation and development of neointimal hyperplasia and subsequent restenosis (39). An upregulation in cell adhesion molecules (CAMs) is the initial event observed after PCI by recruiting leukocytes of monocyte and granulocyte lineage to the damaged vessel wall, followed by monocyte-derived macrophages invading the forming neointima and clustering around the stent struts (37). Other inflammatory cells, including $\mathrm{T}$ cells and neutrophils, have also been reported to be involved in the vascular response to injury and the development of neointimal hyperplasia $(39,40)$. These inflammatory cells secrete various mitogens that play crucial roles in VSMC dedifferentiation, migration, and proliferation (39).
Among the inflammatory cells mentioned above, the diversity and plasticity of macrophages play important roles in multiple biological processes after PCI, including tissue repair, inflammation, foreign body reaction, and restenosis (41). In this study, we showed that JDBM extracts were capable of inhibiting the inflammatory response in LPS-activated macrophages, as well as skewing M1/M2 polarization towards the anti-inflammatory M2 type. These results indicated that consistent with previous studies on biodegradable $\mathrm{Mg}$-based alloys $(15,32,38)$, JDBM had a significant biological effect on the modulation of macrophage function, which could further influence VSMC dedifferentiation, migration, and proliferation. Numerous signaling pathways have been demonstrated in previous studies to be involved in M2 macrophage polarization, including the NF- $\kappa B$, JAK-STAT, Akt-p18-mTOR-LXR, and PTEN/PI3k/AKT pathways, among others (41-43). Of note, the transient receptor potential cation channel subfamily M member 7 (TRPM7), which is a predominant $\mathrm{Mg}^{2+}$ channel in mammalian cells, plays a pivotal role in regulating the functions of macrophages (44). Our previous 
studies reported that $\mathrm{Mg}$ from the degradation products of JDBM inhibited the inflammatory response of THP-1 cellderived macrophages through the TRPM7-PI3K-AKT1 signaling axis.

Furthermore, $\mathrm{Mg}$ ions scavenged intracellular reactive oxygen species (ROS) to prevent the inflammatory response based on the LPS-induced activation of the TLR-4MYD88-NF-кB/MAPK signaling pathway (29). However, up to now, studies on the regulation of macrophage polarization by $\mathrm{Mg}$ ions are still limited. Further studies, for instance, high-throughput multi-omic analyses, are still needed to reveal the underlying mechanism of $\mathrm{Mg}$ on macrophages.

In fact, the crosstalk between macrophages and VSMCs has been well documented in vascular disorders such as atherosclerosis, in-stent restenosis, and vein graft disease $(45,46)$. Furthermore, there is an emerging understanding that there is an interaction between macrophages and VSMCs, and the macrophage secretion profile influences the VSMC phenotype $(28,47)$. For example, PDGF$\mathrm{BB}$, which has been regarded as one of the most potent mitogens and chemoattractants for VSMCs, was reported to induce phenotypic switching, proliferation, migration, and MMP-2 upregulation in VSMCs $(48,49)$. Morisaki et al. reported that macrophages modulate the phenotype of cultured rabbit aortic smooth muscle cells through the secretion of PDGF (50). A similar research group reported that PDGF suppressed the expression of the smooth muscle cell differentiation markers $\alpha$-SMA, SM-MHC, and $\alpha$-tropomyosin in vivo (51). Yang et al. reported that macrophage-derived MMP-8 determined smooth muscle cell differentiation from adventitial stem/progenitor cells and promoted neointimal hyperplasia (52). A recent study also showed that extracellular vesicles derived from macrophage foam cells could promote VSMC migration and adhesion (53). In addition, it was found that some miRNAs were also involved in the crosstalk between macrophages and VSMCs. MiR-195 could inhibit the proinflammatory profile of macrophages and impact crosstalk with smooth muscle cells (45). In this study, we reported that Mg-based JDBM extracts and $\mathrm{MgCl}_{2}$ solutions significantly decreased some macrophage-derived genes, which were reported to promote VSMC phenotypic switching, proliferation, and migration. These results could at least partly explain our later observation of the effect of the different CMs on the proliferation, migration, and polarization of VSMCs.

Our study also has some limitations. First, we used only cell lines and not confirmed in primary human cells because it is hard for us to obtain the primary human cells. Second, we used CM to establish a macrophage-VSMC coculture system in vitro to study the indirect role of $\mathrm{Mg}$ on VSMCs via macrophages. However, the microenvironment and intercellular interactions in vivo are quite complex; thus, the results from in vitro studies can only partly represent the physiological conditions in vivo. In addition, the molecular mechanism underlying the regulation of $\mathrm{Mg}$ on VSMCs via macrophages was not determined in this study, and further research will be done shortly.

\section{Conclusions}

In summary, in the present study, we provide novel insights into the mechanism by which $\mathrm{Mg}$-based alloys function in preventing restenosis, namely, that $\mathrm{Mg}$ ion from the $\mathrm{Mg}$ based alloys could influence VSMC phenotype through modulating macrophage functions. The protective effects of $\mathrm{Mg}$-based alloys make them an exciting therapeutic prospect in further clinical applications of $\mathrm{Mg}$-based vascular stents.

\section{Acknowledgments}

Funding: This work was supported by the National Natural Science Foundation of China (grant numbers: U1804251, 81701626, 81871303 and 51701041), the Committee of Shanghai Science and Technology (grant number: 17DZ2200200), the Medical-Engineering Cross Fund of Shanghai Jiaotong University, China (grant numbers: YG2019ZDA02 and YG2017QN34), and the Interdisciplinary Program of Shanghai Jiaotong University, China (grant number: ZH2018QNA26).

\section{Footnote}

Reporting Checklist: The authors have completed the MDAR reporting checklist. Available at https://dx.doi. org/10.21037/atm-21-1375

Data Sharing Statement: Available at https://dx.doi. org/10.21037/atm-21-1375

Peer Review File: Available at https://dx.doi.org/10.21037/ atm-21-1375

Conflicts of Interest: All authors have completed the ICMJE uniform disclosure form (available at https://dx.doi. org/10.21037/atm-21-1375). The authors have no conflicts 
of interest to declare.

Ethical Statement: The authors are accountable for all aspects of the work in ensuring that questions related to the accuracy or integrity of any part of the work are appropriately investigated and resolved.

Open Access Statement: This is an Open Access article distributed in accordance with the Creative Commons Attribution-NonCommercial-NoDerivs 4.0 International License (CC BY-NC-ND 4.0), which permits the noncommercial replication and distribution of the article with the strict proviso that no changes or edits are made and the original work is properly cited (including links to both the formal publication through the relevant DOI and the license). See: https://creativecommons.org/licenses/by-nc-nd/4.0/.

\section{References}

1. Timmis A, Townsend N, Gale CP, et al. European Society of Cardiology: Cardiovascular Disease Statistics 2019. Eur Heart J 2020;41:12-85.

2. Jellinger PS, Smith DA, Mehta AE, et al. American Association of Clinical Endocrinologists' Guidelines for Management of Dyslipidemia and Prevention of Atherosclerosis. Endocr Pract 2012;18 Suppl 1:1-78.

3. Nahrendorf M, Swirski FK. Lifestyle effects on hematopoiesis and atherosclerosis. Circ Res 2015;116:884-94.

4. Nienaber CA. Guidelines for percutaneous coronary interventions. Eur Heart J 2006;27:1757; author reply 1757-9.

5. Curcio A, Torella D, Indolfi C. Mechanisms of smooth muscle cell proliferation and endothelial regeneration after vascular injury and stenting: approach to therapy. Circ J 2011;75:1287-96.

6. Buccheri D, Piraino D, Andolina G, et al. Understanding and managing in-stent restenosis: a review of clinical data, from pathogenesis to treatment. J Thorac Dis 2016;8:E1150-62.

7. Lacolley P, Regnault V, Nicoletti A, et al. The vascular smooth muscle cell in arterial pathology: a cell that can take on multiple roles. Cardiovasc Res 2012;95:194-204.

8. Fisher SA. Vascular smooth muscle phenotypic diversity and function. Physiol Genomics 2010;42A:169-87.

9. Chistiakov DA, Orekhov AN, Bobryshev YV. Vascular smooth muscle cell in atherosclerosis. Acta Physiol (Oxf) 2015;214:33-50.
10. Frismantiene A, Philippova M, Erne P, et al. Smooth muscle cell-driven vascular diseases and molecular mechanisms of VSMC plasticity. Cell Signal 2018;52:48-64.

11. Hu D, Yin C, Luo S, et al. Vascular Smooth Muscle Cells Contribute to Atherosclerosis Immunity. Front Immunol 2019;10:1101.

12. Salman SA, Ichino R, Okido M. A Comparative Electrochemical Study of AZ31 and AZ91 Magnesium Alloy. J Bio Tribo Corros 2010;2010:1-7.

13. Iqbal J, Gunn J, Serruys PW. Coronary stents: historical development, current status and future directions. Br Med Bull 2013;106:193-211.

14. Zhou Y, Liu X, Huang N, et al. Magnesium ion leachables induce a conversion of contractile vascular smooth muscle cells to an inflammatory phenotype. J Biomed Mater Res B Appl Biomater 2019;107:988-1001.

15. Ma J, Zhao N, Betts L, et al. Bio-Adaption between Magnesium Alloy Stent and the Blood Vessel: A Review. J Mater Sci Technol 2016;32:815-26.

16. Rojaee R, Fathi M, Raeissi K, et al. Biodegradation assessment of nanostructured fluoridated hydroxyapatite coatings on biomedical grade magnesium alloy. Ceram Int 2014;40:15149-58.

17. Li D, Yuan Q, Yu K, et al. Mg-Zn-Mn alloy extract induces the angiogenesis of human umbilical vein endothelial cells via FGF/FGFR signaling pathway. Biochem Biophys Res Commun 2019;514:618-24.

18. Waksman R, Pakala R, Kuchulakanti PK, et al. Safety and efficacy of bioabsorbable magnesium alloy stents in porcine coronary arteries. Catheter Cardiovasc Interv 2006;68:607-17; discussion 618-9.

19. Touyz RM, Yao G. Modulation of vascular smooth muscle cell growth by magnesium-role of mitogen-activated protein kinases. J Cell Physiol 2003;197:326-35.

20. Toutouzas K, Colombo A, Stefanadis C. Inflammation and restenosis after percutaneous coronary interventions. Eur Heart J 2004;25:1679-87.

21. Artiach G, Carracedo M, Clària J, et al. Opposing Effects on Vascular Smooth Muscle Cell Proliferation and Macrophage-induced Inflammation Reveal a Protective Role for the Proresolving Lipid Mediator Receptor ChemR23 in Intimal Hyperplasia. Front Pharmacol 2018;9:1327.

22. Inoue T, Croce K, Morooka T, et al. Vascular inflammation and repair: implications for re-endothelialization, restenosis, and stent thrombosis. JACC Cardiovasc Interv 2011;4:1057-66.

23. Jou IM, Lin CF, Tsai KJ, et al. Macrophage- 
mediated inflammatory disorders. Mediators Inflamm 2013;2013:316482.

24. Rojas J, Salazar J, Martínez MS, et al. Macrophage Heterogeneity and Plasticity: Impact of Macrophage Biomarkers on Atherosclerosis. Scientifica (Cairo) 2015;2015:851252.

25. Peng R, Ji H, Jin L, et al. Macrophage-Based Therapies for Atherosclerosis Management. J Immunol Res 2020;2020:8131754.

26. Mills CD. Anatomy of a discovery: $\mathrm{m} 1$ and $\mathrm{m} 2$ macrophages. Front Immunol 2015;6:212.

27. Carracedo M, Artiach G, Arnardottir H, et al. The resolution of inflammation through omega-3 fatty acids in atherosclerosis, intimal hyperplasia, and vascular calcification. Semin Immunopathol 2019;41:757-66.

28. Koga J, Aikawa M. Crosstalk between macrophages and smooth muscle cells in atherosclerotic vascular diseases. Vascul Pharmacol 2012;57:24-8.

29. Jin L, Chen C, Li Y, et al. A Biodegradable Mg-Based Alloy Inhibited the Inflammatory Response of THP-1 Cell-Derived Macrophages Through the TRPM7-PI3KAKT1 Signaling Axis. Front Immunol 2019;10:2798.

30. Jin $\mathrm{L}, \mathrm{Wu} \mathrm{J}$, Yuan $\mathrm{G}$, et al. In vitro study of the inflammatory cells response to biodegradable $\mathrm{Mg}$-based alloy extract. PLoS One 2018;13:e0193276.

31. Mao L, Yuan G, Niu J, et al. In vitro degradation behavior and biocompatibility of $\mathrm{Mg}-\mathrm{Nd}-\mathrm{Zn}-\mathrm{Zr}$ alloy by hydrofluoric acid treatment. Mater Sci Eng C Mater Biol Appl 2013;33:242-50.

32. Zhang J, Kong N, Shi Y, et al. Influence of proteins and cells on in vitro corrosion of $\mathrm{Mg}-\mathrm{Nd}-\mathrm{Zn}-\mathrm{Zr}$ alloy. Corros Sci 2014;85:477-81.

33. Lai YS, Wahyuningtyas R, Aui SP, et al. Autocrine VEGF signalling on M2 macrophages regulates PD-L1 expression for immunomodulation of T cells. J Cell Mol Med 2019;23:1257-67.

34. Linde N, Lederle W, Depner S, et al. Vascular endothelial growth factor-induced skin carcinogenesis depends on recruitment and alternative activation of macrophages. J Pathol 2012;227:17-28.

35. Wheeler KC, Jena MK, Pradhan BS, et al. VEGF may contribute to macrophage recruitment and M2 polarization in the decidua. PLoS One 2018;13:e0191040.

36. Xu WC, Dong X, Ding JL, et al. Nanotubular $\mathrm{TiO} 2$ regulates macrophage $\mathrm{M} 2$ polarization and increases macrophage secretion of VEGF to accelerate endothelialization via the ERK1/2 and PI3K/AKT pathways. Int J Nanomedicine 2019;14:441-55.
37. Wadey K, Lopes J, Bendeck M, et al. Role of smooth muscle cells in coronary artery bypass grafting failure. Cardiovasc Res 2018;114:601-10.

38. Li Y, Wang L, Chen S, et al. Biodegradable Magnesium Alloy Stents as a Treatment for Vein Graft Restenosis. Yonsei Med J 2019;60:429-39.

39. Liu X, De Scheerder I, Desmet W. Dexamethasone-eluting stent: an anti-inflammatory approach to inhibit coronary restenosis. Expert Rev Cardiovasc Ther 2004;2:653-60.

40. Schillinger M, Minar E. Restenosis after percutaneous angioplasty: the role of vascular inflammation. Vasc Health Risk Manag 2005;1:73-8.

41. Bi Y, Chen J, Hu F, et al. M2 Macrophages as a Potential Target for Antiatherosclerosis Treatment. Neural Plast 2019;2019:6724903.

42. Liu CP, Zhang X, Tan QL, et al. NF-кB pathways are involved in M1 polarization of RAW 264.7 macrophage by polyporus polysaccharide in the tumor microenvironment. PLoS One 2017;12:e0188317.

43. Lu J, Xie L, Liu C, et al. PTEN/PI3k/AKT Regulates Macrophage Polarization in Emphysematous mice. Scand J Immunol 2017;85:395-405.

44. Qiao W, Wong KHM, Shen J, et al. TRPM7 kinasemediated immunomodulation in macrophage plays a central role in magnesium ion-induced bone regeneration. Nat Commun 2021;12:2885.

45. Bras JP, Silva AM, Calin GA, et al. miR-195 inhibits macrophages pro-inflammatory profile and impacts the crosstalk with smooth muscle cells. PLoS One 2017;12:e0188530.

46. Moore KJ, Sheedy FJ, Fisher EA. Macrophages in atherosclerosis: a dynamic balance. Nat Rev Immunol 2013;13:709-21.

47. Khosravi M, Hosseini-Fard SR, Najafi M. System Study of Vascular Smooth Muscle Cell (VSMC) Activation-Related Signaling Pathways by Monocyte and Macrophage Cells. Curr Signal Transduct Ther 2017;12:58-65.

48. Lee MH, Kwon BJ, Koo MA, et al. Mitogenesis of vascular smooth muscle cell stimulated by platelet-derived growth factor-bb is inhibited by blocking of intracellular signaling by epigallocatechin-3-O-gallate. Oxid Med Cell Longev 2013;2013:827905.

49. Lu QB, Wan MY, Wang PY, et al. Chicoric acid prevents PDGF-BB-induced VSMC dedifferentiation, proliferation and migration by suppressing ROS/NF B/mTOR/P70S6K signaling cascade. Redox Biol 2018;14:656-68.

50. Morisaki N, Koyama N, Kawano M, et al. Human macrophages modulate the phenotype of cultured rabbit 
aortic smooth muscle cells through secretion of plateletderived growth factor. Eur J Clin Invest 1992;22:461-8.

51. Holycross BJ, Blank RS, Thompson MM, et al. Plateletderived growth factor-BB-induced suppression of smooth muscle cell differentiation. Circ Res 1992;71:1525-32.

52. Yang F, Chen Q, Yang M, et al. Macrophage-derived MMP-8 determines smooth muscle cell differentiation from adventitia stem/progenitor cells and promotes

Cite this article as: $\mathrm{Wu} \mathrm{J}$, Jin L, Tan JY, Chen XF, Wang QQ, Yuan GY, Chen TX. The effects of a biodegradable Mg-based alloy on the function of VSMCs via immunoregulation of macrophages through $\mathrm{Mg}$-induced responses. Ann Transl Med 2021;9(16):1292. doi: 10.21037/atm-21-1375 neointima hyperplasia. Cardiovasc Res 2020;116:211-25.

53. Niu C, Wang X, Zhao M, et al. Macrophage Foam CellDerived Extracellular Vesicles Promote Vascular Smooth Muscle Cell Migration and Adhesion. J Am Heart Assoc 2016;5:e004099.

(English Language Editors: C. Betlazar-Maseh and J. Chapnick) 